\title{
Hematological aspects of extrahepatic portal vein obstruction in childhood
}

\author{
Çocukluk çağında ekstrahepatik portal ven obstrüksiyonuna hematolojik \\ bakıș açısı
}

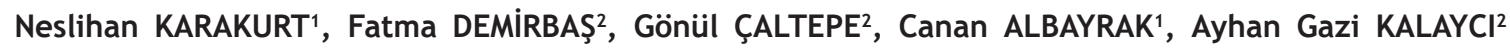

\section{ABSTRACT}

Objective: Extrahepatic portal vein obstruction is rare but considerable cause of portal hypertension (PHT). Patients may present with cytopenia(s) or bleeding, to hematology clinics. The aim of this study is to present our experience of patients with this rare disease and emphasize the value of thrombophilia assessment in portal venous thrombosis (PVT).

Methods: Children admitted to our hospital between June 2006 and October 2018 with diagnosis of extra-hepatic portal venous anomalies are included. Vascular anomalies were defined as trombus and/ or portal cavernoma (PC). The medical reports were assessed retrospectively.

Results: Twelve patients (Female/ Male: 9/ 3) aged 4.6 \pm 3.4 years old are included. The most common complaints on admission were abdominal pain and upper gastrointestinal bleeding. Ten patients (83\%) had cytopenia(s) at diagnosis; eight (67\%) had anemia, five had (42\%) leukopenia and nine had (75\%) thrombocytopenia. Imaging studies revealed thrombus in ten $(83 \%)$ and $\mathrm{PC}$ in ten $(83 \%)$ patients. Five patients

\section{ÖZET}

Amaç: Ekstrahepatik portal ven obstrüksiyonu nadir ancak önemli bir portal hipertansiyon (PHT) nedenidir. Hastalar sitopeni veya kanama ile hematoloji kliniğine bașvurabilirler. Bu çalıșmanın amacı bu hastalardaki tecrübemizi aktarmak ve portal ven trombozunda (PVT) trombofili araștırmasının önemini vurgulamaktır.

Yöntem: Haziran 2006 ve Ekim 2018 tarihleri arasında hastanemize başvuran ve ekstra hepatik portal ven anomalisi tanısı alan çocuklar çalıșmaya dahil edildi. Vasküler anomaliler trombus ve/ veya portal kavernom (PK) olarak ifade edildi. Bulgular retrospektif olarak incelendi.

Bulgular: Yaş ortalaması 4,6 $\pm 3,4$ olan 12 hasta (K/E: 9/3) çalıșmaya dahil edildi. Bașvuruda en sık şikayet karın ağrısı ve gastrointestinal kanamaydı. Hastaların onunda (\%83) sitopeni vardı; sekizi (\%67) anemik, beși (\%42) lökopenik ve dokuzu (\%75) trombositopenikti. Görüntüleme yöntemleri ile on hastada trombus, on hastada portal kavernom (PK) tespit edildi. Beș hastanın umbilikal kateterizasyon hikayesi olup birinde ayrıca

'Samsun Ondokuz Mayis University, Faculty of Medicine, Department of Pediatrics, Division of Hematology, Samsun

${ }^{2}$ Samsun Ondokuz Mayis University, Faculty of Medicine, Department of Pediatrics, Division of Gastroenterology, Samsun

İletişim / Corresponding Author : Neslihan KARAKURT

Ondokuz Mayıs Üni. Tip Fakültesi Hast., Çocuk Hematoloji Bölümü 55000 Samsun - Türkiye

Tel : +90533 3463770 E-posta/E-mail : neslihankarakurt@gmail.com

Geliş Tarihi / Received : 17.04 .2019

Kabul Tarihi/Accepted : 08.09.2019

DOI ID : 10.5505/TurkHijyen.2019.89106

Karakurt N, Demirbaș F, Caltepe G, Albayrak C, Kalaycı AG. Hematological aspects of extrahepatic portal vein obstruction in childhood.

Turk Hij Den Biyol Derg, 2019; 76(4): 415-422 
had a history of umbilical catheterization and one was also positive for homozygous mutation of Factor $V$ Leiden. Four patients were positive for heterozygous mutation of PAI- 1.

Conclusion: PVT during childhood is rare, it may present with thrombocytopenia, splenomegaly and esophageal varices bleeding. Although PVT it is not a common cause of thrombocytopenia in children, clinicians are encouraged to get information regarding history of umbilical catheterization in neonatal period and obtain portal doppler ultrasound in cases with splenomegaly. Further studies about PVT Plasminogen activator inhibitor 1 mutations are needed.

Key Words: Portal vein thrombosis, thrombocytopenia, gastrointestinal system bleeding, splenomegaly, plasminogen activator inhibitor-1
Faktör V Leiden homozigot mutasyonu saptandı. Dört hastada ise PAl-1 heterozigot mutasyonu saptandı.

Sonuç: Çocukluk çağında PVT nadir olup trombositopeni, splenomegali ve özofagial varis kanaması ile prezente olabilir. Çocuklarda PVT trombositopeninin sık bir nedeni olmamasına rağmen klinisyenlerin yenidoğan döneminde umbilikal ven kateterizasyonuyla ilgili bilgi alması ve splenomegalisi olan hastalarda portal doppler USG değerlendirmesi önerilir. PAl-1 mutasyonları ile ilgili daha çok çalıșmaya ihtiyaç vardır.

Anahtar Kelimeler: portal ven trombozu, trombositopeni, gastrointestinal kanama, splenomegali, plazminojen aktivatör inhibitör-1

\section{INTRODUCTION}

Extra hepatic portal vein obstruction (EHPVO) is characterized by a barrier located on the trunk or the branches of portal vein (1). The primary obstruction has usually been referred to portal vein thrombosis (PVT). The term portal cavernoma (PC), or cavernomatous transformation of the portal vein, corresponds to the set of collateral veins replacing the portal vein and thus to a long-standing process. PC $(2,3)$. In adults, PC development is always related to prior thrombosis, whereas in children, PC might also result from a congenital malformation (2).

Although EHPVO is rare in children, it is a considerable cause of extrahepatic portal hypertension (PHT), accounting for up to $75 \%$ of cases in developing countries (3). PVT often occurs during the neonatal period with an estimated incidence of 1.3/100000 live births and 36/ 1000 neonatal intensive care unit (NICU) admissions (4). However, neonatal PVT is often asymptomatic and only identified in the subset of patients who develop symptomatic PHT several years after the initial thrombotic event. Thus the true incidence is likely to be higher (4). The etiology is highly diverse, including umbilical catherization and hypercoagulability states.

The aim of this study is to present our experience of patients with this rare disease and emphasize the value of thrombophilia assessment in PVT.

\section{MATERIAL and METHOD}

Children admitted to our hospital between June 2006 and October 2018 with diagnosis of extrahepatic portal venous anomalies are included in this study. Children with chronic liver disease related to other etiology and patients with cytopenia(s) related to reasons other than hypersplenism are excluded. Autoimmunity (direct anti-globulin test), hemolytic anemia (reticulocytosis), vitamin B12 deficiency (low levels of vitamin B12 in serum) and bone marrow 
failure (malign transformation or hypocellularity in bone marrow, reticulocytopenia); were excluded.

Vascular anomalies were defined as trombus and/ or PC, shown by either Doppler ultrasound, angioMR or angio-CT. The medical reports were assessed retrospectively. Demographic data, complaint on admission, existence of cytopenia(s), data of ultrasound and other imaging modalities, data of endoscopic examination are recorded. Anemia was defined as hemoglobin value less than $11 \mathrm{~g} / \mathrm{dl}$, leukopenia was defined as leukocyte count less than $4.0 \times 103 / \mathrm{mm} 3$ and thrombocytopenia was defined as platelet count below 150x103/ mm3.

Laboratory work-up for chronic liver disease included hepatitis A, B and C serology, autoantibody panel for autoimmune hepatitis (ANA, ASMA, AMA, anti-dsDNA), alpha-fetoprotein, alpha-1 antitrypsin and ceruloplasmin level. Laboratory work-up for thrombophilia included protein C/ S, anti-thrombin three levels and mutation analysis for factor $\mathrm{V}$ Leiden, prothrombin G20210A, methylene-tetra-hydro-folate reductase (MTHFR) C677T and plasminogen activator inhibitor 1 (PAI- 1).

The study was performed in accordance with the Declaration of Helsinki of the World Medical Association.

Data were analyzed statistically with SPSS version 17. Normal distribution of data were assessed by Kolmogorov-Smirnov Test. Since the distribution of variables were normal, scale variables were expressed as mean \pm standard deviation (SD). Categorical data were expressed as number and percentage (\%).

\section{RESULTS}

Twelve patients (Female/ Male: 9/3) are included in study (Table 1). The mean age at presentation was 4.6 3.4 (range: 0.5- 12.5) years. The most common complaints on admission were abdominal pain and upper gastrointestinal bleeding (92\% of total complaints). On admission, splenomegaly was detected in nine (75\%) and hepatomegaly in four (33\%) patients. Ascites was not present in any of patients. Ten patients (83\%) had cytopenia(s) at diagnosis; eight (67\%) had anemia, five (42\%) leukopenia and nine (75\%) thrombocytopenia (Table 1). Pancytopenia was detected in only three (25\%) patient. Two of eight anemic patients had additional thrombocytopenia. Seven patients with anemia had hypersplenism and/ or upper gastrointestinal bleeding whereas one had nutritional iron deficiency anemia. All patients with leucopenia had other cytopenia(s) which was consistent with hypersplenism. The patients without cytopenia $(n=2)$ were at the age of one and 1.5, respectively. None of the patients had prolonged INR nor low albumin level. Full laboratory work- up for chronic liver disease was performed in ten patients and they were all within normal ranges. All patients underwent Doppler USG and/ or angio-MR, angio-CT, which revealed thrombus in ten (83\%), PC in ten (83\%) patients. Bone marrow aspiration was performed in 6 (55\%) patients, which was free of malignancy and aplasia.

Etiological factor for PVT was determined in five patients: all had a history of umbilical catheterization and one was also positive for homozygous mutation of Factor $\mathrm{V}$ Leiden (Table 1 and 2). In addition, seven patients had levels of protein $C$ below normal range; however two of them had levels below $50 \%$. One patient had antithrombin III level of $71 \%$. Four patients were positive for heterozygous mutation of PAl-1 (Table 2). None of patients re-experienced deep venous thrombus.

Eight patients (67\%) underwent upper gastrointestinal system endoscopy; esophageal varices of levels two or three were detected in all of them. In addition to five patients who presented with upper gastrointestinal bleeding, one patients developed it during the follow-up period. None of bleeders required sclerotherapy. All patients with esophageal varices $(n=8)$ were on propranolol continuously. 
Table 1. Clinical and laboratory characteristics of patients with extra-hepatic portal vein obstruction $(n=12)$

\begin{tabular}{|c|c|c|c|}
\hline \multicolumn{2}{|l|}{ Parameter } & \multicolumn{2}{|c|}{$N(\%)$ or mean $\pm 2 S D$ (range) } \\
\hline Age at diagnosis (years) & & $4.6 \pm 3.4$ & (range: $0.5-12,5$ ) \\
\hline Gender (female/ male) & & $9 / 3$ & \\
\hline \multicolumn{4}{|l|}{ Presentation } \\
\hline & Abdominal pain & $6(50 \%)$ & \\
\hline & Upper gastrointestinal bleeding & $5(42 \%)$ & \\
\hline & Epistaxis & $1(8 \%)$ & \\
\hline \multicolumn{4}{|l|}{ Physical findings } \\
\hline & Splenomegaly & $9(75 \%)$ & \\
\hline & Hepatomegaly & $4(33 \%)$ & \\
\hline \multicolumn{4}{|l|}{ Laboratory findings } \\
\hline & Hemoglobin $(\mathrm{g} / \mathrm{dl})$ & $10.0 \pm 2.6$ & (range:3.2- 12.7) \\
\hline & WBC $\left(10^{3} / \mathrm{mm}^{3}\right)$ & $7.5 \pm 6.5$ & (range: $2.1-22.0$ ) \\
\hline & Platelet count $\left(10^{3} / \mathrm{mm}^{3}\right)$ & $160 \pm 120$ & (range: 49-410) \\
\hline & MCV (fl) & $79 \pm 4$ & (range: $72-86$ ) \\
\hline & ALT & $26 \pm 15$ & (range:15- 57) \\
\hline & AST & $43 \pm 21$ & (range: $24-98$ ) \\
\hline & Leukopenia & $5(42 \%)$ & \\
\hline & Thrombocytopenia & $9(75 \%)$ & \\
\hline & Anemia & $8(67 \%)$ & \\
\hline \multicolumn{4}{|l|}{ Imaging findings } \\
\hline & Thrombus & $10(83 \%)$ & \\
\hline & Cavernous transformation & $10(83 \%)$ & \\
\hline \multicolumn{4}{|l|}{ Medication } \\
\hline & Propranolol & $7(64 \%)$ & \\
\hline & Low molecular weight heparin & $5(46 \%)$ & \\
\hline Hypersplenism & & $10(83 \%)$ & \\
\hline Follow-up period (years) & & $5.0 \pm 4.7$ & (range: $1-13$ ) \\
\hline
\end{tabular}

WBC: white blood cell count, MCV: mean corpuscular volume

Liver biopsy was performed in three (27\%) patients, which were did not show abnormality. Two patients required surgical intervention for PHT. Five patients (46\%) were given low molecular weight heparin, any benefit (recanalization of vessel) was not noted. Ten patients $(83 \%)$ had findings of hypersplenism at presentation or during the follow up period. Patients were followed- up for $5.3 \pm 4.5$ years .

\section{DISCUSSION}

Extrahepatic portal vein obstruction is an important cause of PHT. In our study, 12 patients were found to have EHPVO during 12 years period. The mean age at presentation was $4.6 \pm 3.4$ years. Gurekan et al. (5) demonstrated that they diagnosed 12 patients as EHPVT, with a mean age of 5.8 years, 
Table 2. Thrombophilia assessment of patients with extrahepatic portal vein obstruction

\begin{tabular}{|c|c|c|c|c|c|c|c|c|c|c|c|c|}
\hline \multirow[b]{2}{*}{ No. } & \multirow[b]{2}{*}{ Age $(y)$} & \multirow[b]{2}{*}{ Sex } & \multicolumn{2}{|c|}{ Radiology } & \multirow{2}{*}{$\begin{array}{l}\begin{array}{c}\text { Medical } \\
\text { history }\end{array} \\
\text { UVC }\end{array}$} & \multicolumn{3}{|c|}{ Serum levels (\%) } & \multicolumn{4}{|c|}{ Genetic Mutations } \\
\hline & & & Th & PCV & & PC & PS & AT 3 & FVL & Proth. & MTHFR & PAl- 1 \\
\hline 1 & 3 & $\mathrm{~F}$ & + & + & + & 84 & 74 & 93 & - & - & Het+ & Het+ \\
\hline 2 & 12.5 & $\mathrm{~F}$ & + & + & - & NA & NA & NA & - & - & Het+ & Het+ \\
\hline 3 & 1 & M & + & + & - & 64 & 84 & 100 & - & - & - & Het+ \\
\hline 4 & 6.5 & $F$ & + & + & + & 46 & NA & 83 & - & - & - & - \\
\hline 5 & 1.5 & $F$ & - & + & - & 48 & 63 & 84 & - & - & Het+ & - \\
\hline 6 & 0.5 & $\mathrm{~F}$ & + & - & + & 69 & 75 & 81 & - & - & Het+ & - \\
\hline 7 & 5 & $\mathrm{~F}$ & + & - & - & 77 & 53 & 88 & - & - & Het+ & - \\
\hline 8 & 5 & $M$ & - & + & - & NA & NA & NA & - & - & - & - \\
\hline 9 & 5.8 & $F$ & + & + & - & 56 & 71 & 123 & NA & NA & NA & NA \\
\hline 10 & 5.5 & $F$ & + & + & + & 106 & 72 & 124 & Hom+ & Het+ & Het+ & Het+ \\
\hline 11 & 1.5 & $M$ & + & + & + & 57 & 75 & NA & - & - & - & - \\
\hline 12 & 7 & $F$ & + & + & NA & 62 & 78 & 71 & NA & NA & NA & NA \\
\hline
\end{tabular}

Th: Thrombus in portal vein, PCv: Portal cavernoma, UVC: Umbilical venous catherization, PC: Protein C (normal range: 70-110\%), PS: Protein S (normal range: 44-92\%), AT3: Antithrombin III (normal range: 80-120\%), FVL: Factor V Leiden, Proth: Prothrombin G2020A, MTHFR: Methylenetetrahydrofolate reductase C677T, PAI-1: Plasminogen activator inhibitor Hom:Homozygous, Het: Heterozygous, NA: Not applicable

during 14 years of period. The studies with larger populations from Egypt (6) and India (7) showed that the average age at diagnosis was 2.5 and 12.5, respectively. The wide range of age at presentation is remarkable. We speculate that this may be related to social and economical status of regions and opportunity to reach satisfactory medical evaluation.

We detected that the most common complaint on admission was a"bdominal pain and hematemesis. In recent similar reports, hematemesis from bleeding esophageal varices is the most common presenting symptom in children with PVT and it is the most serious complication of PHT in all ages (3, 6, 8- 9). EHPVO may not be discovered until gastrointestinal hemorrhage develops (10). Bleeding episodes may be preceded by a brief febrile illness and are often recurrent without treatment (3). In our study, splenomegaly was detected in nine patients, which seems to be similar to other studies $(3,6)$. The presentation in neonates may be different than older children. Morag et al. (11) demonstrated that the most common indications for ultrasound in neonates (before diagnosing PVT) were thrombocytopenia (20\%), abdominal distension (17\%), elevated liver enzymes $(7 \%)$ and hepatosplenomegaly (4\%).

We detected that at presentation, ten patients $(83 \%)$ had cytopenia: nine of them had thrombocytopenia. All patients with thrombocytopenia had splenomegaly, which was attributed to hypersplenism. Thrombocytopenia is a common finding in children admitted to hospital. The differential diagnosis has a wide range including infection related cytopenia, nutritional deficiencies, autoimmune disorders, bone marrow failure syndromes, malignant diseases and hypersplenism. Hypersplenism is a diagnosis made with the exclusion of other diagnoses. Although it is not a common etiology in children, clinicians are encouraged 
to get information regarding history of umbilical catheterization in neonatal period and obtain portal doppler ultrasound in cases with splenomegaly. Eight patients were detected to have anemia at diagnosis. In EHPVO, anemia may be either due to bleeding or hypersplenism. Anemia related to hypersplenism is usually accompanied by thrombocytopenia and/ or leukopenia. As mentioned above, six patients with anemia had additional cytopenia(s), one had severe anemia due to upper gastrointestinal bleeding (hemoglobin level: $3.2 \mathrm{~g} / \mathrm{dl}$ ) and one had only nutritional iron deficiency anemia. In our study group, five (42\%) patients had leukopenia, which was attributed to hypersplenism. However the differential diagnosis is similar to that of thrombocytopenia. Bone marrow aspiration examination is frequently performed in order to rule out malignancy and aplastic anemia.

Thrombus was determined in ten $(83 \%)$ and PC was detected in ten (83\%) patients. In the presence of PVT, compensatory dilatation of hepatic artery and development of collateral vessels constitutes a tangle of tortuous vessels in the porta hepatis, which is named cavernous transformation (3). Criteria for dating thrombus development rely on imaging findings at the time of presentation. Solid endoluminal material in the absence of well-developed portoportal collaterals for PVT is recent onset and large porto-portal collaterals without recognizable portal vein is for chronic PVT. Doppler ultrasound, CT scan, and MRI provide information of similar accuracy (2), However it can be diagnosed in children with PVT by Doppler ultrasound faster than other methods with advantage of showing splenomegaly and portosystemic collaterals (12).

Liver biopsy was requested by consultant and performed in three patients, which were within normal limits of microscopic examination. The necessity of liver biopsy is considerable. In a recent review, it is not recommended for diagnosis if evidence for portal venous obstruction has been obtained by noninvasive imaging. But in special circumstances like the need to distinguish thrombosis from malignant invasion or rule out underlying cirrhosis/ vascular portosinusoidal disease, liver biopsy is indicated (2).

In half of our patients, the risk factors for development of PVT could not be elicited from the medical history and laboratory. Similarly, in literature, predisposing conditions for PVT are obscure in more than half of the cases; in other cases umbilical vein catheterization, omphalitis, and sepsis are most commonly incriminated in children $(3,4)$. None of our patients had omphalitis nor sepsis, but five patients had a history of umbilical catheterization. Because neonatal PVT is often asymptomatic, the diagnosis is often an incidental finding of imaging performed for other indications. PVT during the childhood period can be described by the presence of prothrombotic disorders, such as factor $\mathrm{V}$ Leiden mutation, Protein C, Protein S and antithrombin III deficiency (4).

In our study, two patients had low levels of Protein C: which were 46-48\%. Plasma levels of Protein C below 50\% (normal range, 70-110\%) are associated with the risk of thrombotic complications (13). It is well known that Protein C level may be temporary low, due to several factors including vitamin $\mathrm{K}$ deficiency or acute thrombus and may not reveal hereditary deficiency; repeating the test may be necessary. Unfortunately our patients had only one measurement for Protein C. One of our patients had a homozygous mutation of Factor $\mathrm{V}$ Leiden, and had additional Prothrombin G2020A (heterozygous) mutation. Antithrombin III, Protein C and Protein S deficiency are defined as 'high risk thrombophilia' whereas carrier status of Factor $\mathrm{V}$ Leiden and Prothrombin G2020A mutations are defined as 'low risk thrombophilia (13-14). Homozygous individuals for Factor $V$ Leiden have a higher risk of thombosis $(13-14)$. It is important to declare that none of our patients with thrombophilia developed additonal thrombi during the follow-up period.

Our laboratory also include other, less well 
established polymorphisms in its thrombophilia panel, such as MTHFR 677TT and PAI-1 4G/5G. Four patients had PAl-1 polymorphism (4G/ 5G) and five had heterozygous mutation of MTHFR 677TT. PAI1 is the main regulator of endogenous fibrinolysis. Several studies have been performed on PAI- 1 polymorphisms and it is shown to be related to several diseases including osteonecrosis (15) and diabetes mellitus (16), probably by causing micro-vascular complications. Association of PAl-1 polymorphism with VTE is limited (17). In a recent study on childhood thrombosis, none of patients had PAI-1 polymorphism with elevated serum PAl-1 activity (18). The lack of our study is the measurement of PAl- 1 activity. Further studies are needed to analyze the association of PAI- 1 and thrombosis, particularly PVT in this context. In a recent metaanalysis (19), it is established that there is no significant association with venous thromboembolism and homozygous C677TMTHFR mutations.

Portal vein thrombosis after splenectomy has been reported (20). Neverthless, none of our patients had splenectomy.

Anticoagulation and thrombolytic treatment is controversial in PVT. In neonates with acute, occlusive PVT and no contraindication, 6-12 weeks of anticoagulation is reasonable (4). After the acute period, during late infancy and childhood, in patients who are at risk for bleeding or for non-occlusive PVT; supportive care, and serial ultrasound monitoring may be appropriate. Anticoagulation is not indicated for PC due to high rate of variceal bleeding. Paliative therapies includes beta adrenergic antogonists, endoscopic variceal band ligation or endoscopic sclerotherapy (4). In our study group seven patients received propranolol treatment and five received low molecular weight heparin.

In conclusion, PVT during childhood is rare, it may present with thrombocytopenia, splenomegaly and esophageal varices bleeding. Doppler ultrasound for portal venous system is a noninvasive and easy method for diagnosis. The catheterization of the umbilical vein has now long been implicated as a cause for PVT presenting in childhood, and we recommend to get a detailed medical history in patients with PVT. Most of children with PVT do not have congenital thrombophilia. Considering risk of bleeding, anticoagulation is not encoured in long

\section{REFERENCES}

1. European Association for the Study of the Liver. Electronic address: easloffice@easloffice.eu. EASL Clinical Practice Guidelines: Vascular diseases of the liver. J Hepatol. 2016;64(1):179-202.

2. Valla DC, Cazals-Hatem D. Vascular liver diseases on the clinical side:definitions and diagnosis, new concepts. Virchows Arch. 2018;473(1):3-13.

3. Giouleme O, Theocharidou E. Management of portal hypertension in children with portal vein thrombosis.. J Pediatr Gastroenterol Nutr. 2013;57(4):419-25.

4. Kumar R, Kerlin BA. Thrombosis of the Abdominal Veins in Childhood. Front Pediatr. 2017 Sep 5;5:188.
5. Gürakan F, Eren M, Koçak N, Yüce A, Ozen H, Temizel IN, Demir H. Extrahepatic portal vein thrombosis in children: etiology and long-term follow-up. J Clin Gastroenterol. 2004;38(4):368-72.

6. El-Karaksy HM, El-Koofy N, Mohsen N, Helmy $\mathrm{H}$, Nabil N, El-Shabrawi M. Extrahepatic portal vein obstruction in Egyptian children. J Pediatr Gastroenterol Nutr. 2015;60(1):105-9.

7. Jain M, Jain J, Passi GR, Jain K, Jain S. Profile of extrahepatic portal venous obstruction among children in Central India. Clin Exp Hepatol. 2017;3(4):209-211. 
8. Sokal EM, Van Hoorebeeck N, Van Obbergh L, Otte JB, Buts JP. Upper gastro-intestinal tract bleeding in cirrhotic children candidates for liver transplantation. Eur J Pediatr. 1992;151(5):326-8.

9. Sharara Al, Rockey DC. Gastroesophageal variceal hemorrhage. N Engl J Med. 2001;345(9):669-81. Review.

10. Radovich PA. Portal vein thrombosis and liver disease. J Vasc Nurs. 2000;18(1):1-5. Review.

11. Morag I, Epelman M, Daneman A, Moineddin R, Parvez B, Shechter T, Hellmann J. Portal vein thrombosis in the neonate: risk factors, course, and outcome. J Pediatr. 2006;148(6):735-9.

12. Rajpurkar M, SharathkumarA, Williams S, Lau K, Ling SC, Chan AK Recommendations for the assessment of non-extremity venous thromboembolism outcomes: communication from the SSC of the ISTH. Pediatric/ Neonatal Hemostasis and Thrombosis Scientific and Standardization Subcommittee of the International Society on Thrombosis and Haemostasis. J Thromb Haemost. 2015;13(3):477-80.

13. Middeldorp S. Inherited thrombophilia: a doubleedged sword. Hematology Am Soc Hematol Educ Program 2016; 2016: 1-9.

14. Celkan T, Dikme G. Thrombosis in children: Which test to whom, when and how much necessary? Turk Pediatri Ars. 2018;53(1):1-9.
15. Sobhan MR, Mahdinezhad-Yazdi M, Moghimi M, Aghili K, Jafari M, Zare-Shehneh M,Neamatzadeh $\mathrm{H}$. Plasminogen Activator Inhibitor-1 4G/5G Polymorphism Contributes to Osteonecrosis of the Femoral Head Susceptibility: Evidence from a Systematic Review and Meta-analysis. Arch Bone Jt Surg. 2018;6(6):468-477.

16. Adly AA, Elbarbary NS, Ismail EA, Hassan SR. Plasminogen activator inhibitor-1(PAl-1) in children and adolescents with type 1 diabetes mellitus: relation to diabetic micro-vascular complications and carotid intima media thickness. J Diabetes Complications. 2014;28(3):340-7.

17. Gohil R, Peck G, Sharma P. The genetics of venous thromboembolism. A meta-analysis involving approximately 120,000 cases and 180,000 controls. Thromb Haemost. 2009;102(2):360-370.

18. Mahajerin A, Obasaju P, Eckert G, Vik TA, Mehta R, Heiny M. Thrombophilia testing in children: a 7 year experience. Pediatr Blood Cancer.2014;61(3):523-7.

19. Simone B, De Stefano V, Leoncini E. Risk of venous thromboembolism associated with single and combined effects of factor $\mathrm{V}$ Leiden, prothrombin 20210A and methylenetethraydrofolate reductase C677T: a metaanalysis involving over 11,000 cases and 21,000 controls. Eur J Epidemiol 2013; 28: 62147.

20. Winslow ER, Brunt ML, Drebin JA, et al. Portal vein thrombosis after splenectomy. Am J Surg. 2002; 184:631-636. 